\title{
Structure and Biosynthesis of FD-594; a New Antitumor Antibiotic
}

\author{
Katsuya Kondo, Tadashi Eguchi and Katsumi Kakinuma* \\ Department of Chemistry, Tokyo Institute of Technology, \\ O-okayama, Meguro-ku, Tokyo 152-8551, Japan \\ Kazutoshi Mizoue and Ya-Fang QiaO \\ Medicinal Research Laboratories, Taisho Pharmaceutical Co., Ltd., \\ 1-403, Yoshino-cho, Omiya-shi, Saitama 330-8530, Japan
}

(Received for publication January 9, 1998)

The structure of a novel antitumor antibiotics FD-594 (1), produced by Streptomyces sp. TA-0256, was determined to have a glycosylated pyrano[ $\left.4^{\prime}, 3^{\prime}: 6,7\right]$ naphtho[1,2-b]xanthene skeleton by means of spectral data. The biosynthetic studies of the chromophore of 1 was also carried out by feeding experiments with $\left[1-{ }^{13} \mathrm{C}\right]-,\left[2-{ }^{13} \mathrm{C}\right]-$, and $\left[1,2-{ }^{13} \mathrm{C}_{2}\right]$ sodium acetate. The labeling pattern was determined by ${ }^{13} \mathrm{C}$ NMR including 2D INADEQUATE experiments, which allowed us to elucidate that the chromophore of 1 is derived from 14 acetate, followed by the loss of one carbon atom.

In the course of screening for new antitumor antibiotics, it was found that an acetone extract from Streptomyces sp. TA-0256 inhibited growth of several cancer cell lines, and subsequent bioassay-guided purification of the active principle resulted in the isolation of a new antibiotics, designated as FD-594 (1) ${ }^{1}$. In this paper, we wish to report the structure elucidation of 1 by making extensive use of the ${ }^{13} \mathrm{C}$-enriched metabolite. Also described is the biosynthetic pathway of the chromophoric part of $\mathbf{1}$.

\section{Results and Discussion}

The physico-chemical properties of $\mathbf{1}$ are summarized in Table 1. The molecular formula of $\mathbf{1}$ was established as $\mathrm{C}_{47} \mathrm{H}_{56} \mathrm{O}_{20}$ by the HR-FAB mass spectrometry. The IR absorptions at 1667 and $1624 \mathrm{~cm}^{-1}$ suggested the existence of $\alpha, \beta$-unsaturated carbonyl groups. The UVvisible maxima at 420 and $363 \mathrm{~nm}$ in methanol were shifted to 440 and $379 \mathrm{~nm}$, respectively, in the presence of $\mathrm{NaOH}$ in methanol, which strongly suggested the presence of phenolic hydroxyl group(s). The ${ }^{1} \mathrm{H}$ NMR spectra showed the presence of three phenolic protons $\left(\delta_{\mathrm{H}} 11.8,11.9\right.$, and 12.3$)$ in $\mathrm{CDCl}_{3}$. The ${ }^{1} \mathrm{H}$ NMR data

Fig. 1. Structures of FD-594 (1).

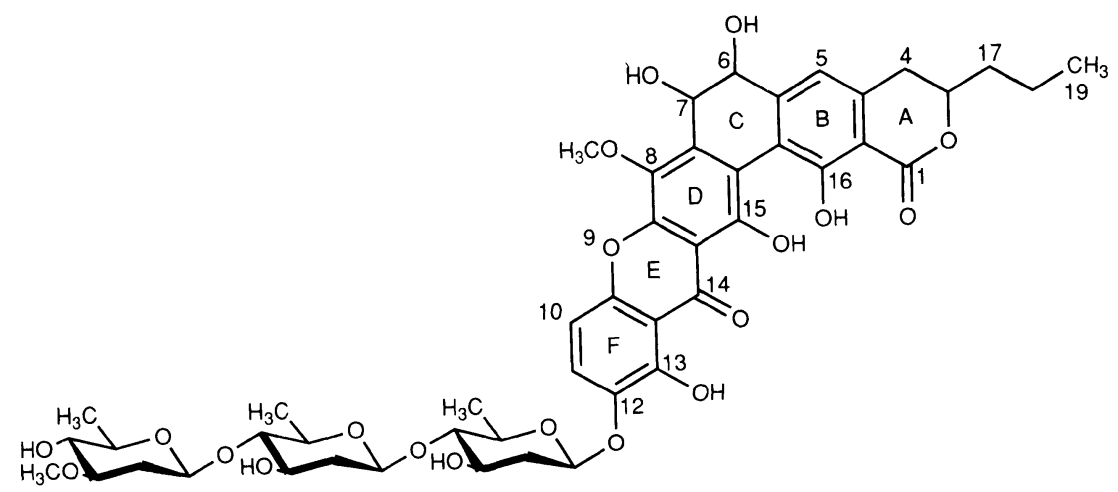


Table 1. Physico-chemical properties of $\mathbf{1}$

\begin{tabular}{ll}
\hline Appearance & Yellow powder \\
Melting point & $199 \sim 202^{\circ} \mathrm{C}$ \\
Molecular formula & $\mathrm{C}_{47} \mathrm{H}_{56} \mathrm{O}_{20}$ \\
FAB-MS $(m / z)$ & $941(\mathrm{M}+\mathrm{H})^{+}$ \\
HR FAB-MS $(m / z)$ & \\
$\quad$ Found & $941.3530(\mathrm{M}+\mathrm{H})^{+}$ \\
$\quad$ Calcd. & $941.3443(\mathrm{M}+\mathrm{H})^{+}$ \\
{$[\alpha]_{\mathrm{D}}^{26}$} & $-215^{\circ}\left(c 0.58, \mathrm{CHCl}_{3}\right)$ \\
$\mathrm{UV} \lambda_{\text {max }} / \mathrm{nm}(\varepsilon)$ & \\
in MeOH & $420(3200), 363(12600)$, \\
& $276(27500)$, \\
& $233(23200)$, \\
& $214(24800)$ \\
in $0.1 \mathrm{M} \mathrm{NaOH} / \mathrm{MeOH}$ & $440 \mathrm{sh}(5200)$, \\
& $379(11700)$, \\
& $277(21400)$, \\
IR $v_{\text {max }} / \mathrm{cm}^{-1}(\mathrm{KBr})$ & $232(26300)$ \\
Rf value on TLC & $3436,1667,1624,1575$, \\
\hline
\end{tabular}

a Silica gel TLC (Merck Art. 5715); $\mathrm{CHCl}_{3}$ methanol $(10: 1)$

of $\mathbf{1}$ are shown in Table 2.

The ${ }^{13} \mathrm{C}$ NMR spectra of $\mathbf{1}$ displayed limited carbon signals $(44 \sim 45$ signals $)$ in various solvents $\left(\mathrm{CDCl}_{3}\right.$, acetone- $d_{6}$, DMSO- $d_{6}$, pyridine- $d_{5}$ ) probably due to slow conformational exchange. Since the characteristically high degree of unsaturation suggested the origin of the chromophore of $\mathbf{1}$ to be polyketide (polyacetate, rather), we undertook preparation of ${ }^{13} \mathrm{C}$-enriched specimen for ${ }^{13} \mathrm{C}$ NMR analysis by feeding either $\left[1-{ }^{13} \mathrm{C}\right]-$ or $\left[2-{ }^{13} \mathrm{C}\right]$ sodium acetate into the growing culture of Streptomyces TA-0256. The resulting ${ }^{13} \mathrm{C}$ labeled antibiotic was extracted from the mycelia and purified by a flash chromatography and a preparative reverse phase HPLC. The ${ }^{13} \mathrm{C}$ NMR spectra of 1 labeled from $\left[1-{ }^{13} \mathrm{C}\right]$ - and $\left[2-{ }^{13} \mathrm{C}\right]$ sodium acetate showed 13 and 14 enriched signals, respectively. These ${ }^{13} \mathrm{C}$-enriched products were extremely useful for the following structure determination. The ${ }^{13} \mathrm{C}$ NMR peak intensities of 1 labeled by $\left[1-{ }^{13} \mathrm{C}\right]$ - and $\left[2-{ }^{13} \mathrm{C}\right]$ sodium acetate feeding were summarized in Table 3. By combining all the ${ }^{13} \mathrm{C}$ NMR data obtained from labeled and non-labeled 1 together, we were able to locate the presence of 47 carbons, which were then classified into several categories, i.e. two $\alpha, \beta$-unsaturated carbonyl carbons $\left(\delta_{\mathrm{C}}\right.$ 186.2 and 170.3), ten $s p^{2}$ quaternary carbons $\left(\delta_{\mathrm{C}} 159.0\right.$, $153.8,152.1,151.3,148.9,144.7,140.1,140.0,138.9$, and 136.9), three $s p^{2}$ methine carbons $\left(\delta_{\mathrm{C}} 129.6,113.3\right.$, and 106.3), five $s p^{2}$ quaternary carbons $\left(\delta_{\mathrm{C}} 115.4,112.0\right.$,
Table 2. ${ }^{1} \mathrm{H}$ and ${ }^{13} \mathrm{C}$ NMR spectral data for $\mathbf{1}$ in $\mathrm{CDCl}_{3}\left(50^{\circ} \mathrm{C}\right)$.

\begin{tabular}{|c|c|c|}
\hline Positions & $\begin{array}{c}{ }^{13} \mathrm{C} \text { Chemical } \\
\text { shifts } \\
\text { (multiplicity) }\end{array}$ & $\begin{array}{l}{ }^{1} \mathrm{H} \text { Chemical shifts } \\
\text { (multiplicity, } J \text { in } \mathrm{Hz} \text { ) }\end{array}$ \\
\hline 1 & $170.3(\mathrm{~s})$ & \\
\hline 3 & $79.3(\mathrm{~d})$ & $4.61(\mathrm{~m})$ \\
\hline 4 & $33.2(\mathrm{t})$ & $3.0(\mathrm{~m})$ \\
\hline $4 a$ & $140.1(\mathrm{~s})^{\mathrm{a}}$ & \\
\hline 5 & 113.3 (d) & $7.09(\mathrm{~s})$ \\
\hline $5 \mathrm{a}$ & $144.7(\mathrm{~s})$ & \\
\hline 6 & 73.2 (d) & 4.67 (brd, 9.3) \\
\hline 7 & 74.0 (d) & $4.81(\mathrm{brd}, 9.3)$ \\
\hline $7 a$ & $138.9(\mathrm{~s})$ & \\
\hline 8 & $136.9(\mathrm{~s})$ & \\
\hline $8 \mathrm{a}$ & $148.9(\mathrm{~s})$ & \\
\hline $9 \mathrm{a}$ & $151.3(\mathrm{~s})$ & \\
\hline 10 & $106.3(d)$ & $6.96(\mathrm{~d}, 9.1)$ \\
\hline 11 & $129.6(d)$ & $7.56(\mathrm{~d}, 9.1)$ \\
\hline 12 & $140.0(\mathrm{~s})^{\mathrm{a}}$ & \\
\hline 13 & $152.1(\mathrm{~s})$ & \\
\hline $13 \mathrm{a}$ & $108.5(\mathrm{~s})^{\mathrm{b}}$ & \\
\hline 14 & $186.2(\mathrm{~s})$ & \\
\hline $14 \mathrm{a}$ & $107.8(\mathrm{~s})$ & \\
\hline 15 & $153.8(\mathrm{~s})$ & \\
\hline $15 \mathrm{a}$ & $112.0(\mathrm{~s})$ & \\
\hline $15 b$ & $115.4(\mathrm{~s})$ & \\
\hline 16 & $159.0(\mathrm{~s})$ & \\
\hline $16 \mathrm{a}$ & $108.6(\mathrm{~s})^{\mathrm{b}}$ & \\
\hline 17 & $36.9(\mathrm{t})$ & $1.7(\mathrm{~m}), 1.9(\mathrm{~m})$ \\
\hline 18 & $18.1(\mathrm{t})$ & $1.5(\mathrm{~m}), 1.6(\mathrm{~m})$ \\
\hline 19 & $13.7(q)$ & $1.00(\mathrm{t}, 7.3)$ \\
\hline $8-\mathrm{OCH}_{3}$ & $62.9(\mathrm{q})$ & $3.40(\mathrm{~s})$ \\
\hline $13-\mathrm{OH}$ & & $11.8(\mathrm{~s})$ \\
\hline $15-\mathrm{OH}$ & & $12.3(\mathrm{~s})$ \\
\hline $16-\mathrm{OH}$ & & $11.9(\mathrm{~s})$ \\
\hline $1^{\prime}$ & $99.6(d)$ & $5.14(\mathrm{dd}, 2.0,9.7)$ \\
\hline $2^{\prime}$ & $38.6(t)^{c}$ & $\begin{array}{l}1.9(\mathrm{~m}) \\
2.60(\mathrm{ddd} 2.0,5.4,12.6)\end{array}$ \\
\hline $3^{\prime}$ & $69.5(d)^{\mathrm{d}}$ & $3.71(\mathrm{ddd}, 5.4,8.6,12.1)$ \\
\hline $4^{\prime}$ & $88.7(\mathrm{~d})$ & $3.02(\mathrm{t}, 8.6)$ \\
\hline $5^{\prime}$ & $70.9(\mathrm{~d})$ & $3.4(\mathrm{~m})$ \\
\hline $6^{\prime}$ & $17.6(q)^{e}$ & $1.30(\mathrm{~d}, 6.1)$ \\
\hline $1^{\prime \prime}$ & $101.1(\mathrm{~d})^{\mathrm{f}}$ & $4.50(\mathrm{dd}, 1.8,9.8)$ \\
\hline $2^{\prime \prime}$ & $38.1(\mathrm{t})^{\mathrm{c}}$ & $\begin{array}{l}1.6(\mathrm{~m}) \\
2.29(\mathrm{ddd}, 1.8,5.3,13.0)\end{array}$ \\
\hline $3^{\prime \prime}$ & $69.4(d)^{d}$ & $3.36(\mathrm{ddd}, 5.3,8.6,12.4)$ \\
\hline $4^{\prime \prime}$ & 87.9 (d) & $3.07(\mathrm{t}, 8.6)$ \\
\hline $5^{\prime \prime}$ & 70.9 (d) & $3.5(\mathrm{~m})$ \\
\hline $6^{\prime \prime}$ & $17.6(q)^{\mathrm{e}}$ & $1.34(\mathrm{~d}, 6.3)^{\mathrm{g}}$ \\
\hline $1^{\prime \prime \prime}$ & $101.2(d)^{f}$ & $4.51(\mathrm{~m})$ \\
\hline $2^{\prime \prime \prime}$ & $35.3(\mathrm{t})$ & $\begin{array}{l}1.5(\mathrm{~m}) \\
2.35(\mathrm{ddd}, 2.1,4.5,12.5)\end{array}$ \\
\hline $3^{\prime \prime \prime}$ & $80.4(d)$ & $3.2(\mathrm{~m})$ \\
\hline $4^{\prime \prime \prime}$ & $75.2(\mathrm{~d})$ & $3.2(\mathrm{~m})$ \\
\hline $5^{\prime \prime \prime}$ & $72.3(\mathrm{~d})$ & $3.4(\mathrm{~m})$ \\
\hline $6^{\prime \prime \prime}$ & $17.8(\mathrm{q})^{\mathrm{e}}$ & $1.36(\mathrm{~d}, 6.1)^{\mathrm{g}}$ \\
\hline $3^{\prime}-\mathrm{OH}$ & & $4.49(\mathrm{~s})$ \\
\hline $3 "-\mathrm{OH}$ & & $4.54(\mathrm{~s})$ \\
\hline $3^{\prime \prime \prime}-\mathrm{OCH}_{3}$ & $56.5(q)$ & $3.41(\mathrm{~s})$ \\
\hline $4^{\prime \prime \prime}-\mathrm{OH}$ & & $2.41(\mathrm{~s})$ \\
\hline
\end{tabular}

$\mathrm{a} \sim \mathrm{g} \quad$ May be interchangeable within the column. 
Table 3. Enrichment levels and coupling constants of the aglycon of 1 produced by sodium $\left[1-{ }^{13} \mathrm{C}\right]-,\left[2-{ }^{13} \mathrm{C}\right]-$ or $\left[1,2-{ }^{13} \mathrm{C}\right]$ acetate feeding.

\begin{tabular}{|c|c|c|c|}
\hline \multirow{2}{*}{ Position } & \multicolumn{2}{|c|}{ Peak enhancement } & \multirow{2}{*}{$\begin{array}{c}\text { Coupling constants }(\mathrm{Hz}) \\
{\left[1,2-{ }^{13} \mathrm{C}\right] \mathrm{NaOAc}}\end{array}$} \\
\hline & {$\left[1{ }^{13} \mathrm{C}\right] \mathrm{NaOAc} \mathrm{c}^{\mathrm{a}}$} & {$\left[2-{ }^{13} \mathrm{C}\right] \mathrm{NaOAc}{ }^{\mathrm{a}}$} & \\
\hline 1 & 7.3 & 1.0 & 66.6 \\
\hline 3 & 8.2 & 1.1 & 39.5 \\
\hline 4 & 0.5 & 8.3 & 41.1 \\
\hline $4 a$ & 7.8 & 1.0 & 41.1 \\
\hline 5 & nd & 4.0 & nd \\
\hline $5 \mathrm{a}$ & 8.3 & nd & 59.3 \\
\hline 6 & 0.8 & 7.6 & 41.1 \\
\hline 7 & 2.7 & nd & nd \\
\hline $7 a$ & 0.5 & 6.1 & 73.2 \\
\hline 8 & 7.1 & nd & 73.2 \\
\hline $8 a$ & 0.7 & 6.2 & $\mathrm{~s}$ \\
\hline $9 a$ & 0.7 & 6.6 & 65.0 \\
\hline 10 & 8.5 & 1.0 & 59.2 \\
\hline 11 & 0.7 & 6.3 & 59.2 \\
\hline 12 & 8.7 & 1.0 & 79.0 \\
\hline 13 & 0.7 & 5.8 & 79.0 \\
\hline $13 a$ & 5.3 & 1.1 & 65.0 \\
\hline 14 & 0.5 & 7.9 & 57.6 \\
\hline $14 \mathrm{a}$ & 5.4 & nd & 57.6 \\
\hline 15 & 0.7 & 7.7 & 74.0 \\
\hline $15 \mathrm{a}$ & 6.6 & 0.9 & 74.0 \\
\hline $15 b$ & nd & 6.8 & 72.4 \\
\hline 16 & 7.7 & 1.0 & 72.4 \\
\hline $16 \mathrm{a}$ & nd & 5.9 & 66.6 \\
\hline 17 & 0.6 & 7.5 & 39.5 \\
\hline 18 & 11.1 & 1.1 & 34.5 \\
\hline 19 & 0.7 & 8.4 & 34.5 \\
\hline $8-\mathrm{OCH}_{3}$ & 1.0 & 1.0 & $\mathrm{~s}$ \\
\hline
\end{tabular}

108.6, 108.5, and 107.8), fifteen oxygenated $s p^{3}$ methine carbons $\left(\delta_{\mathrm{C}} 101.2,101.1,99.6,88.7,87.9,80.4,79.3,75.2\right.$, $74.0,73.2,72.3,70.9,70.9,69.5$, and 69.4), three $s p^{3}$ methylene carbons $\left(\delta_{\mathrm{C}} 38.6,38.1,36.9,35.3,33.2\right.$, and $18.1)$, four methyl carbons $\left(\delta_{\mathrm{C}} 17.8,17.6,17.6\right.$, and 13.7), and two methoxy carbons $\left(\delta_{\mathrm{C}} 62.9,56.5\right)$.

The ${ }^{1} \mathrm{H}-{ }^{1} \mathrm{H}$ COSY spectra showed that 1 contains a trisaccharide moiety. Detailed analysis of the spincoupling data and ${ }^{1} \mathrm{H}^{-1} \mathrm{H}$ COSY spectra as well as HMBC experiments revealed that the trisaccharide moiety of 1 consisted of one 2,6-dideoxy-3- $O$-methyl- $\beta$ arabino-hexopyranoside (oleandrose) unit and two 2,6dideoxy- $\beta$-arabino-hexopyranosides (olivose) units. The positions of the glycoside linkages between these hexopyranose were determined by the HMBC spectra. The HMBC correlations of $\mathrm{H}-1^{\prime \prime \prime}\left(\delta_{\mathrm{H}} 4.51\right)$ with the C-4" $\left(\delta_{\mathrm{H}}\right.$ 87.9), and $\mathrm{H}-1^{\prime \prime}\left(\delta_{\mathrm{H}} 4.50\right)$ with the C-4' $\left(\delta_{\mathrm{H}} 88.7\right)$ clearly indicated the connectivities of the pyranose units, which was further verified by acetylation of 1 to its octa-acetate 2 [FAB-MS $m / z: 1299\left(\mathrm{M}^{+}+\mathrm{Na}\right)$ ]. Significant shifts of the methine signals to the lower field were observed at $\mathrm{H}-3^{\prime}\left(\delta_{\mathrm{H}} 5.2\right), \mathrm{H}-3^{\prime \prime}\left(\delta_{\mathrm{H}} 5.2\right)$, and $\mathrm{H}-4^{\prime \prime \prime}$ $\left(\delta_{\mathrm{H}} 4.88\right)$ by acetylation.

The ${ }^{1} \mathrm{H}-{ }^{1} \mathrm{H}$ COSY and HMBC experiments, particularly by the use of ${ }^{13} \mathrm{C}$-enriched 1 , confirmed the homo- and heteronuclear connectivities in $\mathbf{1}$, which are shown in Figure 2. The HMBC correlations of the C-12 with the anomeric proton of $\mathrm{H}^{-1}{ }^{\prime}$ indicated the glycosylated position. Other HMBC correlations from the aromatic protons, $\mathrm{H}-3, \mathrm{H}-6, \mathrm{H}-7$, and the phenolic protons suggested the structure of the aglycon part of 1 as 3-propylpyrano[ $\left[4^{\prime}, 3^{\prime}: 6,7\right]$ naphtho[1,2-b]xanthene skeleton.

The carbon connectivities of the aglycon part of 1 was 
Fig. 2. ${ }^{1} \mathrm{H}^{-1} \mathrm{H}$ COSY and $\mathrm{HMBC}$ connectivities of $\mathbf{1}$

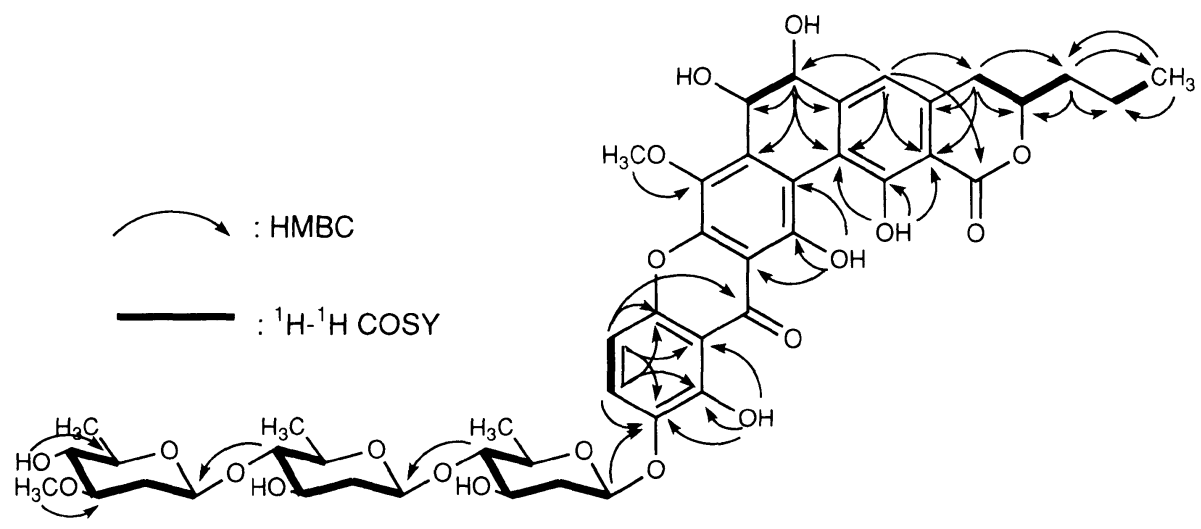

Fig. 3. The 2D INADEQUATE spectrum of 1 enriched with the double labeled acetate.

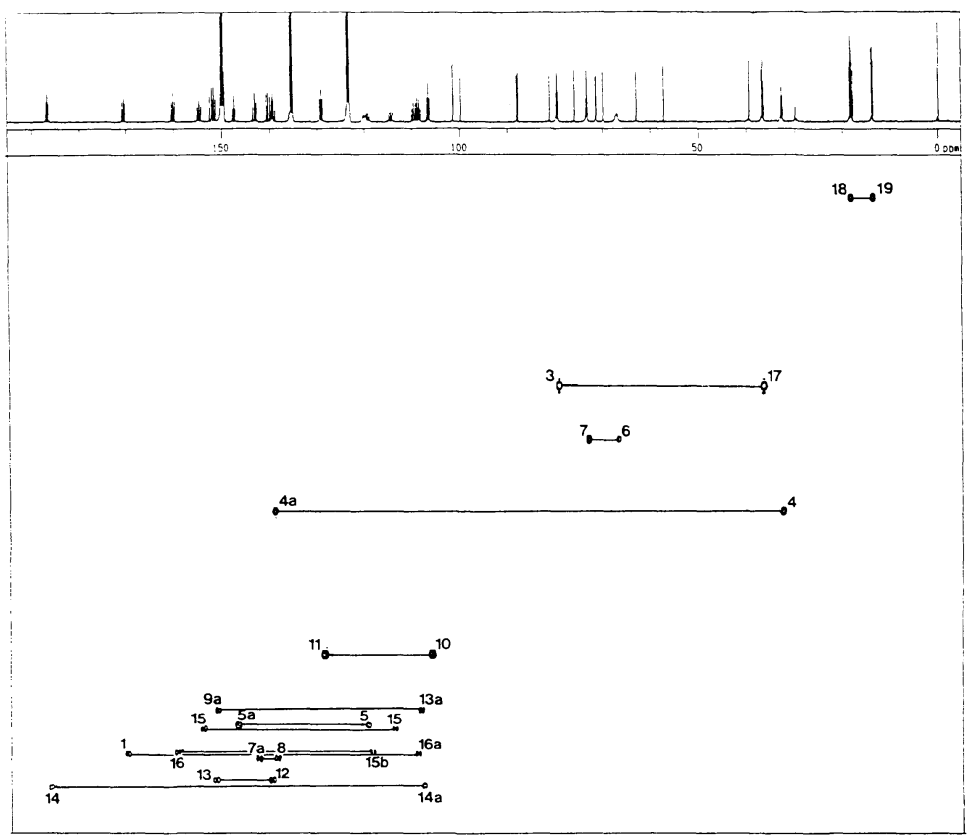

further confirmed by the use of labeling with $[1,2-$ ${ }^{13} \mathrm{C}_{2}$ ] sodium acetate by similar feeding experiment as described above. The ${ }^{13} \mathrm{C}$ NMR spectrum of 1 enriched with the double-labeled acetate showed all carbons of the aglycon part of 1 as triplet except for the methoxy carbon and C-8a. The latter (C-8a) was observed as an enriched singlet. All the $\mathrm{C}-\mathrm{C}$ spin couplings due to incorporation of intact acetate were confirmed by 2D INADEQUATE experiment as shown in Figure 3, which clearly indicated the connectivities of acetate units in the aglycon part of 1 as summarized in Figure 4. The coupling constants obtained for the $\left[1,2-{ }^{13} \mathrm{C}_{2}\right]$ acetate enriched 1 are also listed in Table 3. Thus, the structure of $\mathbf{1}$ was
Fig. 4. The carbon-carbon connectivities in the aglycon part of 1 deduced by double-labeled acetate.

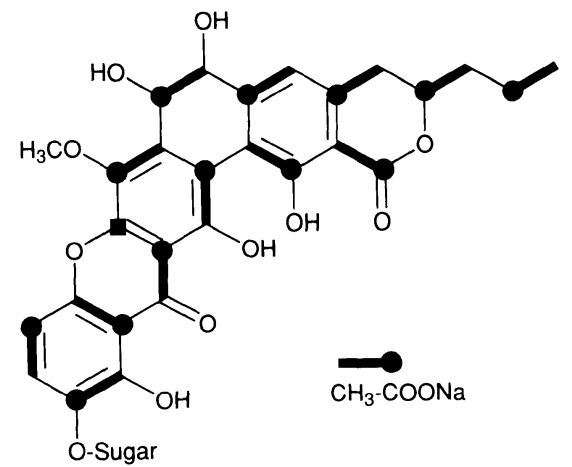


Fig. 5. Structures of BE-13973X and MS 901809.

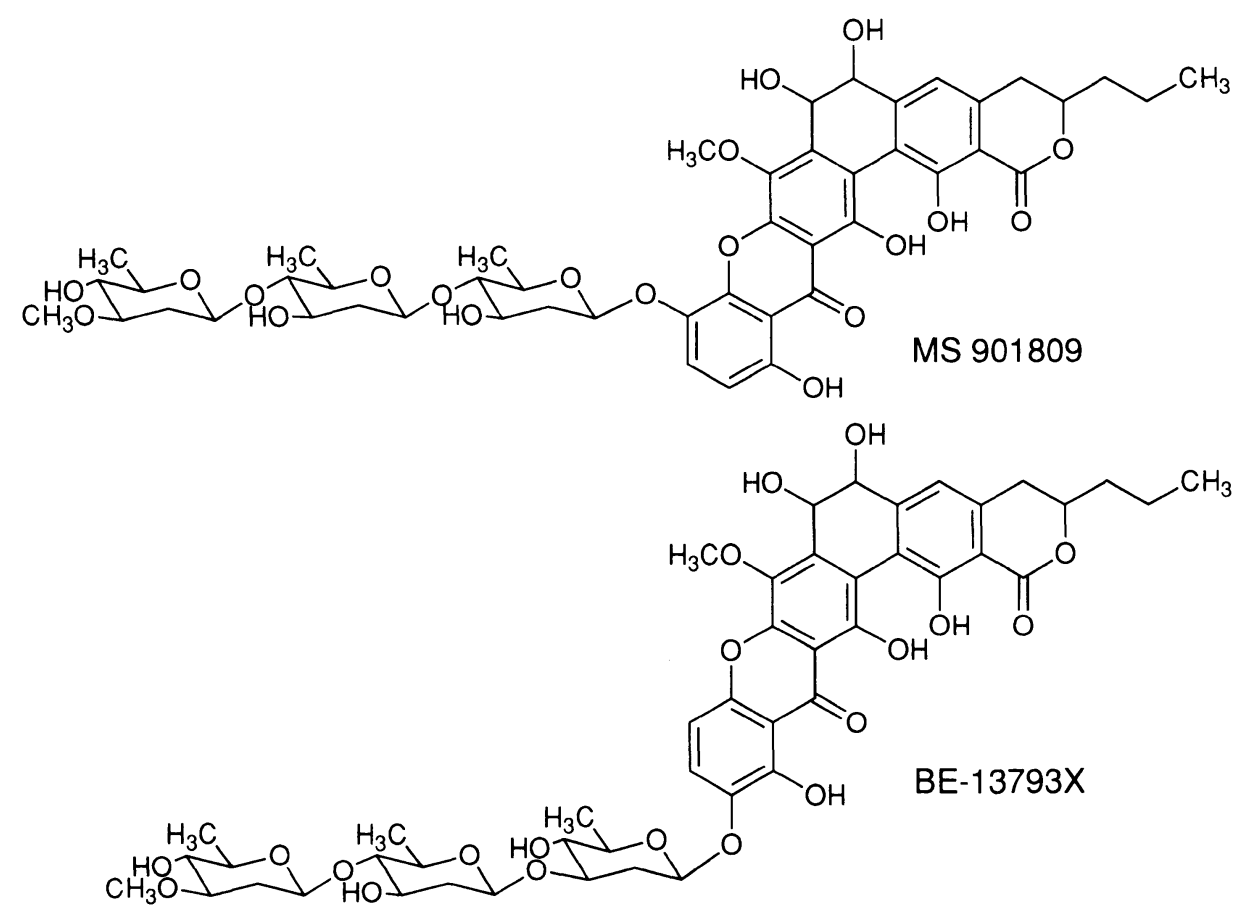

Fig. 6. Degradation of $\mathbf{1}$.

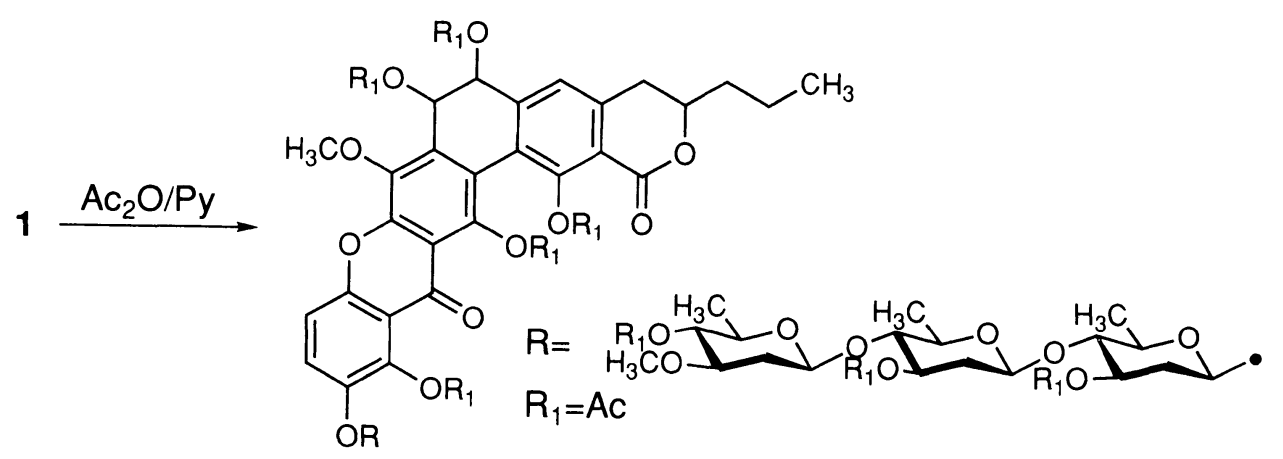<smiles>CCCC1Cc2cc3c(c(O)c2C(=O)O1)-c1c(c(OC)c2oc4ccc(O)c(O)c4c(=O)c2c1O)C(O)C3O</smiles>

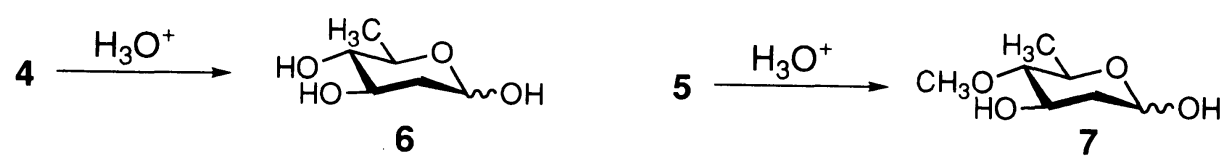


Fig. 7. Plausible biosynthetic pathway of $\mathbf{1}$.

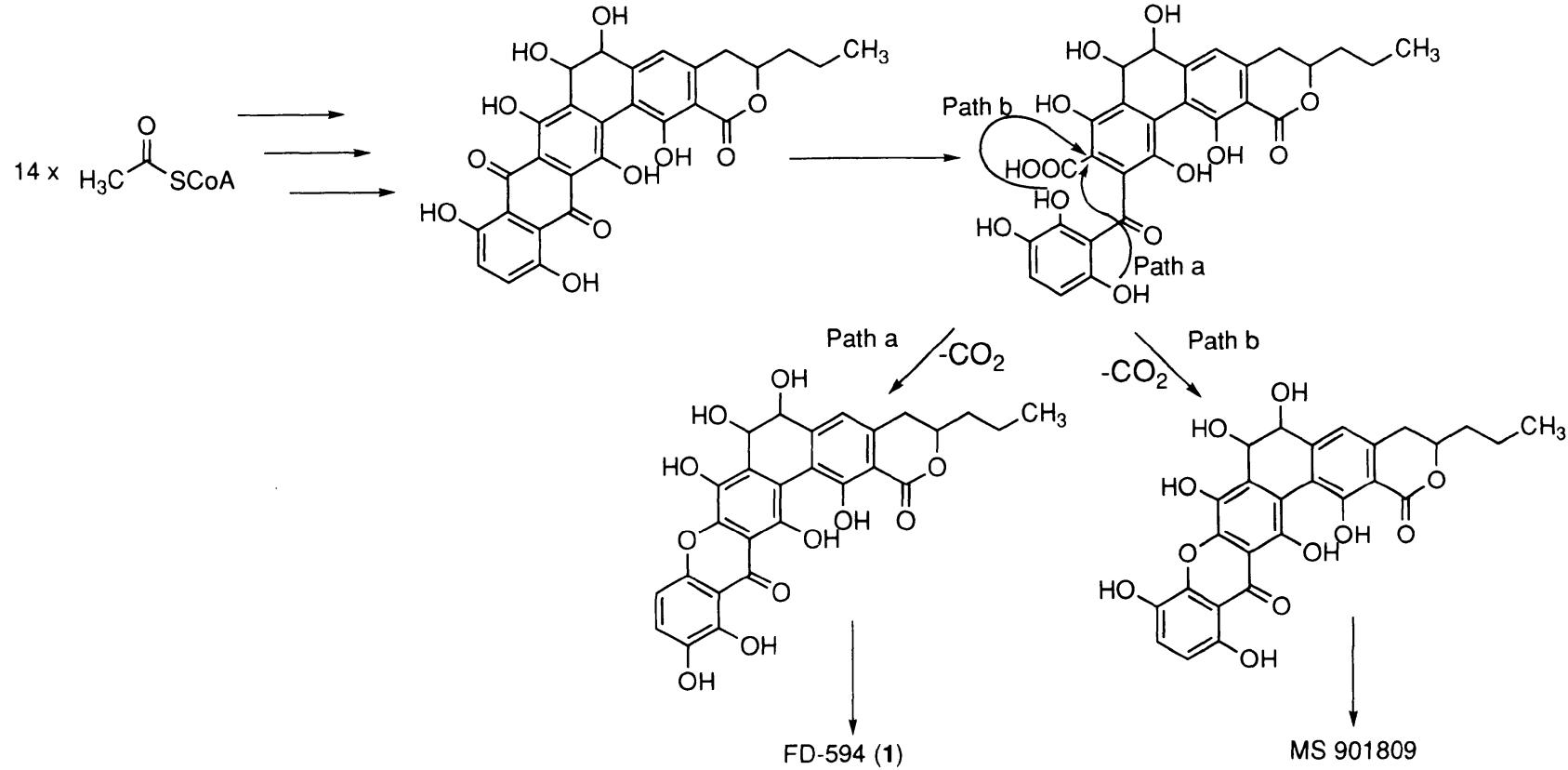

deduced to be 12-[(O-2,6-dideoxy-3- $O$-methyl- $\beta$-arabinohexopyranosyl- $(1 \rightarrow 4)$ - $O$-2,6-dideoxy- $\beta$-arabino-hexopyranosyl-( $1 \rightarrow 4)$-2,6-dideoxy- $\beta$-arabino-hexopyranosyl)oxy]-3,4,6,7-tetrahydro-6,7,13,15,16-pentahydroxy-8methoxy-3-propylpyrano[ $\left[4^{\prime}, 3^{\prime}: 6,7\right]$-naphtho[1,2-b]xanthene-1,14-dione. The structure of 1 was actually closely related to BE-13973X ${ }^{2)}$ and MS $901809^{3)}$, both of which were reported to be isolated also from Streptomyces.

The absolute configurations of the oleandroside and the olivoside were determined as shown in Figure 6. Acidic methanolysis of $\mathbf{1}$ gave the aglycon 3, methyl olivoside 4, and methyl oleandroside 5. The aglycon 3 was in good accordance with BE-13793XA derived from BE-13793X in all spectroscopic respects. Further acid hydrolysis of these glycosides $\mathbf{4}$ and $\mathbf{5}$ afforded the known sugar 6 and 7. The absolute stereochemistry of the obtained 6 and 7 was determined to be $\mathrm{D}$ by their optical rotations $\left[6:+18.9^{\circ}\left(\text { lit. }+20^{\circ}\right)^{4}\right), 7:-12.0^{\circ}$ (lit. $\left.\left.-12.5^{\circ}\right)^{5)}\right]$. The absolute stereochemistry of the aglycon moiety of $\mathbf{1}$ is now under study.

The carbon skeleton of the chromophore of $\mathbf{1}$ appeared to be constructed through a polyacetate equivalent as deduced by feeding experiments of labeled acetate. As a results, the biosynthetic pattern of the chromophore of 1 is postulated to be as shown in Figure 7. In an early stage, the benzo $[\alpha]$ naphthacene quinone chromophore may first be derived from 14 acetate units as in the case of pradimicin family of antibiotics ${ }^{6 \sim 8)}$. Thereafter, the Baeyer-Villiger type oxidation occurs at a quinone carbonyl group, followed by additional oxidation and decarboxylation to yield a ring-opened intermediate. Recyclization via path a leads to $\mathbf{1}$, an alternative recyclization via path $\mathbf{b}$ may afford structurally related MS 901809.

In summary, the structure of a novel antitumor antibiotics FD-594 (1) was determined to have a glycosylated pyrano $\left[4^{\prime}, 3^{\prime}: 6,7\right]$ naphtho[ $[1,2-b]$ xanthene skeleton by means of spectral data including various ${ }^{13} \mathrm{C}$-enriched products, prepared by feeding experiments with $\left[1-{ }^{13} \mathrm{C}\right]$-, $\left[2-{ }^{13} \mathrm{C}\right]$-, and $\left[1,2-{ }^{13} \mathrm{C}_{2}\right]$ sodium acetate. The labeling pattern was unambiguously determined by the $2 \mathrm{D}$ INADEQUATE experiment. The labeling experiments additionally allowed us to postulate the biosynthesis of the chromophore of $\mathbf{1}$, which appears to be derived from 14 acetate units accompanied by the loss of one carbon atom.

\section{Experimental}

\section{General}

UV-visible spectra were recorded on a Shimadzu UV$160 \mathrm{~A}$ spectrophotometer. IR spectra were taken on a HORIBA FT-710 spectrometer and optical rotations were measured on a JASCO DIP-360 polarimeter. FAB-MS and HRFAB-MS were recorded by a JEOL 
spectrometer model JMS-AX 505HA. The 1D and 2D NMR spectra were obtained on JEOL LA-300 and/or 400 spectrometers. A flash column chromatography was performed using Merck Silica gel 60 (230 400 mesh). Preparative HPLC were carried out using a Hitachi L-6250 HPLC system with a Senshu Pak Pegasil ODS column (20 i.d. $\times 250 \mathrm{~mm}$ ). Sodium $\left[1-{ }^{13} \mathrm{C}\right],\left[2-{ }^{13} \mathrm{C}\right]$, and $\left[1,2-{ }^{13} \mathrm{C}_{2}\right]$ acetates were purchased from ISOTEC Inc.

\section{Acetylation of $\mathbf{1}$}

FD-594 (1) (10.2 mg) was acetylated overnight with $\mathrm{Ac}_{2} \mathrm{O}(0.4 \mathrm{ml})$ in pyridine $(0.8 \mathrm{ml})$ at room temperature. After concentration of the mixture, the crude product was purified by a flash silica gel column chromatography with hexane - EtOAc $(2: 3)$ and preparative HPLC $(85 \%$ $\mathrm{MeOH}$ aq.) to give $4.0 \mathrm{mg}$ of octa-acetylated FD-594 (2), pale yellow powder, mp $152 \sim 155^{\circ} \mathrm{C} ;[\alpha]_{\mathrm{D}}^{29}:+179^{\circ}(c$ $\left.0.89, \mathrm{CHCl}_{3}\right) ; \mathrm{UV} \lambda_{\text {max }} / \mathrm{nm}$ in methanol $(\varepsilon): 364$ (4100), 324 (6900), 273 (38300), 218 (30300); IR $v_{\max } / \mathrm{cm}^{-1}$ $\left(\mathrm{CHCl}_{3}\right): 1741,1664,1617,1604,1479,1463,1371,1236$, 1199, 1060; FAB-MS m/z: $1299\left(\mathrm{M}^{+}+\mathrm{Na}\right) ;{ }^{1} \mathrm{H}$ NMR (benzene- $\left.d_{6}\right) \delta: 7.35(1 \mathrm{H}, \mathrm{d}, J=9.3 \mathrm{~Hz}), 7.32(1 \mathrm{H}, \mathrm{s}), 6.85$ $(1 \mathrm{H}, \mathrm{d}, J=3.4 \mathrm{~Hz}), 6.80(1 \mathrm{H}, \mathrm{d}, J=9.3 \mathrm{~Hz}), 6.28(1 \mathrm{H}, \mathrm{d}$, $J=3.4 \mathrm{~Hz}), 5.2(2 \mathrm{H}, \mathrm{m}), 4.88(1 \mathrm{H}, \mathrm{t}, J=9.3 \mathrm{~Hz}), 4.75$ $(1 \mathrm{H}, \mathrm{dd}, J=2.0,9.3 \mathrm{~Hz}), 4.37(1 \mathrm{H}, \mathrm{dd}, J=2.0,9.5 \mathrm{~Hz})$, $4.36(1 \mathrm{H}, \mathrm{dd}, J=2.2,9.5 \mathrm{~Hz}), 3.95(1 \mathrm{H}, \mathrm{br}), 3.29(\mathrm{t}$, $J=9.0 \mathrm{~Hz}), 3.78(3 \mathrm{H}, \mathrm{s}), 3.31(1 \mathrm{H}, \mathrm{t}, J=8.8 \mathrm{~Hz}), 3.20$ (4H, m), $3.09(3 \mathrm{H}, \mathrm{s}), 2.50(3 \mathrm{H}, \mathrm{m}), 2.30(3 \mathrm{H}, \mathrm{s}), 2.26$ $(1 \mathrm{H}, \mathrm{ddd}, J=2.2,5.4,12.3 \mathrm{~Hz}), 2.21(3 \mathrm{H}, \mathrm{s}), 2.12(1 \mathrm{H}$, ddd, $J=2.0,5.1,12.4 \mathrm{~Hz}), 1.99(1 \mathrm{H}$, ddd, $J=9.3,11.5$, $12.5 \mathrm{~Hz}), 1.91(3 \mathrm{H}, \mathrm{s}), 1.90(1 \mathrm{H}, \mathrm{m}), 1.86(3 \mathrm{H}, \mathrm{s}), 1.77$ $(3 \mathrm{H}, \mathrm{s}), 1.71(\mathrm{dt}, J=9.8,12.3 \mathrm{~Hz}), 1.65(\mathrm{dt}, J=9.5$, $12.4 \mathrm{~Hz}), 1.60(3 \mathrm{H}, \mathrm{s}), 1.60(1 \mathrm{H}, \mathrm{m}), 1.49(6 \mathrm{H}, \mathrm{s}), 1.27$ $(1 \mathrm{H}, \mathrm{d}, J=5.8 \mathrm{~Hz}), 1.22(1 \mathrm{H}, \mathrm{d}, J=6.1 \mathrm{~Hz}), 1.21(1 \mathrm{H}, \mathrm{d}$, $J=5.8 \mathrm{~Hz}), 1.20(2 \mathrm{H}, \mathrm{m}), 0.71(3 \mathrm{H}, \mathrm{t}, J=7.1 \mathrm{~Hz}) ;{ }^{13} \mathrm{C}$ NMR (benzene- $d_{6}$ ) $\delta: 174.7,169.8,169.6,169.4$ (2C), $169.3,169.2(2 \mathrm{C}), 168.2,161.6,151.5,150.6,149.7,146.5$, $145.7,143.3,141.4,140.9,138.7,132.0,128.6,126.0$, 125.7, 121.9, 121.3, 118.1, 117.3, 115.2, 100.4, 100.1, 99.5, $81.7,81.6,78.2,77.5,76.0,72.0,71.8,70.9$ (2C), 70.8, $69.6,64.6,62.5,56.1,37.6,36.9(3 \mathrm{C}), 33.6,21.3(2 \mathrm{C})$, $21.1,21.0,20.7,20.6,20.4,20.2,18.5,18.4$ (2C), 18.1, 13.8 .

\section{Methanolysis of 1}

A mixture of $1(79 \mathrm{mg})$ and approximately $1.0 \mathrm{ml}$ of Dowex 50W-X8 $\left(\mathrm{H}^{+}\right.$form) ion-exchange resin in $4.0 \mathrm{ml}$ of methanol was stirred at room temperature for 6 hours. The resin was filtered off and the filtrate was concentrated. Silica gel chromatography (EtOAc $-\mathrm{CHCl}_{3}=1: 1$ to $\left.\mathrm{CHCl}_{3}: \mathrm{MeOH}: \mathrm{H}_{2} \mathrm{O}=65: 25: 4\right)$ of the residue gave $8.9 \mathrm{mg}$ of methyl oleandroside $(\alpha / \beta=6: 1), 27.1 \mathrm{mg}$ of methyl olivoside $(\alpha / \beta=5: 1)$ and aglycon of FD-594. The aglycon was further purified by gel filtration with Sephadex $\mathrm{LH}-20$ using $\mathrm{CHCl}_{3}-\mathrm{MeOH}(1: 1)$ to give $20.7 \mathrm{mg}$ of aglycon 3 as an orange amorphous powder; $[\alpha]_{\mathrm{D}}^{27}:-295^{\circ}\left(c 0.66, \mathrm{CHCl}_{3}\right)$; UV $\lambda_{\max } / \mathrm{nm}$ in $\mathrm{MeOH}(\varepsilon)$ : 429 (3300), 368 (11200), 281 (29100), 234 (18100) 215 (23400); IR $v_{\text {max }} / \mathrm{cm}^{-1}\left(\mathrm{CHCl}_{3}\right): 3451,1654,1625,1490$, 1457, 1257, 1234, 1056; FAB-MS $m / z: 537\left(\mathrm{M}^{+}+\mathrm{H}\right) ;{ }^{1} \mathrm{H}$ NMR (DMSO- $\left.d_{6}\right): \delta 12.28(3 \mathrm{H}, \mathrm{s}), 11.68(3 \mathrm{H}, \mathrm{s}), 11.53$ $(3 \mathrm{H}, \mathrm{s}), 9.50(3 \mathrm{H}, \mathrm{s}), 7.39(1 \mathrm{H}, \mathrm{d}, J=9.0 \mathrm{~Hz}), 7.08(1 \mathrm{H}$, $\mathrm{d}, J=9.0 \mathrm{~Hz}), 6.91(1 \mathrm{H}, \mathrm{s}), 5.46(2 \mathrm{H}, \mathrm{s}), 5.03(1 \mathrm{H}$, br t $)$, $4.77(1 \mathrm{H}$, br m), $4.53(1 \mathrm{H}$, br t $), 3.95(3 \mathrm{H}, \mathrm{s}), 3.15(1 \mathrm{H}$, $\mathrm{dd}, J=3.4,16.4 \mathrm{~Hz}), 2.97(1 \mathrm{H}, \mathrm{dd}, J=9.8,16.5 \mathrm{~Hz}), 1.79$ $(1 \mathrm{H}, \mathrm{m}), 1.69(1 \mathrm{H}, \mathrm{m}), 1.49(2 \mathrm{H}, \mathrm{m}), 0.95(3 \mathrm{H}, \mathrm{t}, J=$ $7.3 \mathrm{~Hz}$ ); ${ }^{13} \mathrm{C}$ NMR (DMSO- $\left.d_{6}\right): \delta 185.8,169.7,158.0$, $152.7,148.3,147.9,146.8,145.7,140.9,140.6,138.9$, $137.8,124.8,119.7,117.6,112.5,108.3,107.8,107.1$, 106.4, 79.2, 71.1, 64.3, 62.4, 35.8, 31.6, 17.6, 13.5. Methyl olivoside 4; ${ }^{1} \mathrm{H}$ NMR $\left(\mathrm{CDCl}_{3}\right) \alpha$-anomer: $\delta 4.78(1 \mathrm{H}$, $\mathrm{dd}, J=1.2,3.7 \mathrm{~Hz}), 3.66(1 \mathrm{H}, \mathrm{dq}, J=9.0,6.1 \mathrm{~Hz}), 3.49$ $(1 \mathrm{H}$, ddd, $J=4.9,9.0,11.5 \mathrm{~Hz}), 3.34(3 \mathrm{H}, \mathrm{s}), 3.33(3 \mathrm{H}$, s), $3.16(1 \mathrm{H}, \mathrm{t}, J=9.0 \mathrm{~Hz}), 2.48(1 \mathrm{H}, \mathrm{br} \mathrm{s}), 2.27(1 \mathrm{H}, \mathrm{ddd}$, $J=3.7,4.9,12.7 \mathrm{~Hz}), 1.51 \quad(1 \mathrm{H}, \mathrm{ddd}, J=1.2,11.5$, $12.7 \mathrm{~Hz}), 1.31(3 \mathrm{H}, \mathrm{d}, J=6.1 \mathrm{~Hz})$. Methyl oleandroside 5; ${ }^{1} \mathrm{H}$ NMR $\left(\mathrm{CDCl}_{3}\right) \alpha$-anomer: $\delta 4.73,(1 \mathrm{H}, \mathrm{d}, J=$ $3.2 \mathrm{~Hz}), 3.85(1 \mathrm{H}$, ddd, $J=4.9,9.0,11.7 \mathrm{~Hz}), 3.59(1 \mathrm{H}$, $\mathrm{dq}, J=9.0,6.2 \mathrm{~Hz}), 3.32(3 \mathrm{H}, \mathrm{s}), 3.07(1 \mathrm{H}, \mathrm{t}, J=9.0 \mathrm{~Hz})$, $2.12(1 \mathrm{H}, \mathrm{dd}, J=4.9,12.7 \mathrm{~Hz}), 1.67(1 \mathrm{H}, \mathrm{ddd}, J=3.2$, $11.7,12.7 \mathrm{~Hz}), 1.29(3 \mathrm{H}, \mathrm{d}, J=6.2 \mathrm{~Hz})$.

\section{Hydrolysis of Methyl Olivoside 4}

Methyl olivoside $4(21.4 \mathrm{mg})$ was hydrolyzed in $0.1 \mathrm{~N}$ $\mathrm{H}_{2} \mathrm{SO}_{4}(1.0 \mathrm{ml})$ at $70^{\circ} \mathrm{C}$ for 2 hours. The solution was neutralized by addition of aq. $\mathrm{Ba}(\mathrm{OH})_{2}$ and the precipitate was filtered off. The filtrate was concentrated to give $16.8 \mathrm{mg}$ of olivose $6 ;{ }^{1} \mathrm{H}$ NMR $\left(\mathrm{D}_{2} \mathrm{O} ; \alpha / \beta=5: 4\right)$ $\alpha$-anomer $\delta: 5.14(1 \mathrm{H}, \mathrm{dd}, J=1.0,9.3 \mathrm{~Hz}), 3.70(2 \mathrm{H}, \mathrm{m})$, $2.93(1 \mathrm{H}, \mathrm{t}, J=9.5 \mathrm{~Hz}), 1.95(1 \mathrm{H}, \mathrm{ddd}, J=1.0,5.1$, $13.4 \mathrm{~Hz}), 1.54(1 \mathrm{H}, \mathrm{ddd}, J=3.7,11.9,13.4 \mathrm{~Hz}), 1.09(3 \mathrm{H}$, $\mathrm{d}, J=6.2 \mathrm{~Hz}) ; \beta$-anomer $\delta: 4.74(1 \mathrm{H}, \mathrm{dd}, J=2.0,9.8 \mathrm{~Hz})$, 3.49 ( $1 \mathrm{H}$, ddd, $J=5.3,9.3,11.8 \mathrm{~Hz}), 3.25(1 \mathrm{H}, \mathrm{dd}, J=7.1$, $9.3 \mathrm{~Hz}), 2.88(1 \mathrm{H}, \mathrm{t}, J=9.3 \mathrm{~Hz}), 2.08(1 \mathrm{H}, \mathrm{ddd}, J=2.0$, $5.3,11.8 \mathrm{~Hz}), 1.35(1 \mathrm{H}, \mathrm{dt}, J=9.8,11.8 \mathrm{~Hz}), 1.11(3 \mathrm{H}, \mathrm{d}$, $J=7.1 \mathrm{~Hz}) .[\alpha]_{\mathrm{D}}^{29}:+18.9^{\circ}\left(c 0.56, \mathrm{H}_{2} \mathrm{O}\right) ;$ lit. $^{4)}+20^{\circ}(c$ 1.6, $\left.\mathrm{H}_{2} \mathrm{O}\right)$.

Hydrolysis of Methyl Oleandroside 5

Methyl oleandroside $5(8.9 \mathrm{mg})$ was hydrolyzed in $40 \%$ 
acetic acid in water $(1.25 \mathrm{ml})$ at $90^{\circ} \mathrm{C}$ for 7 hours. The solvent was evaporated to give $6.6 \mathrm{mg}$ of oleadrose $7 ;{ }^{1} \mathrm{H}$ NMR $\left(\mathrm{CDCl}_{3}, \alpha / \beta=5: 3\right)$ : $\alpha$-anomer $\delta: 5.29(1 \mathrm{H}, \mathrm{d}$, $J=3.7 \mathrm{~Hz}), 3.88(3 \mathrm{H}, \mathrm{dq}, J=9.3,6.3 \mathrm{~Hz}), 3.60(1 \mathrm{H}, \mathrm{m})$, $3.40(3 \mathrm{H}, \mathrm{s}), 3.18(1 \mathrm{H}, \mathrm{m}), 2.46(1 \mathrm{H}, \mathrm{br} \mathrm{s}), 2.32(1 \mathrm{H}$, ddd, $J=1.2,4.8,12.8 \mathrm{~Hz}), 1.50(1 \mathrm{H}, \mathrm{ddd}, J=3.7,12.5$, $12.8 \mathrm{~Hz}), 1.30(3 \mathrm{H}, \mathrm{d}, J=6.3 \mathrm{~Hz}) ; \beta$-anomer $\delta: 4.81(1 \mathrm{H}$, $\mathrm{dd}, J=1.8,9.7 \mathrm{~Hz}), 3.41(3 \mathrm{H}, \mathrm{s}), 3.40(1 \mathrm{H}, \mathrm{m}), 3.18(1 \mathrm{H}$, $\mathrm{m}), 2.79$ ( $1 \mathrm{H}, \mathrm{br} \mathrm{s}), 2.43(1 \mathrm{H}, \mathrm{ddd}, J=1.8,4.4,12.5 \mathrm{~Hz})$, $1.36(1 \mathrm{H}, \mathrm{m}), 1.35(3 \mathrm{H}, J=6.1 \mathrm{~Hz}) ;[\alpha]_{\mathrm{D}}^{29}:-12.0^{\circ}(c$ $\left.0.66, \mathrm{H}_{2} \mathrm{O}\right)$; lit. ${ }^{5)}-12.5^{\circ}\left(c 3.669, \mathrm{H}_{2} \mathrm{O}\right)$.

\section{Feeding Experiments}

Inoculum of Streptomyces sp. TA-0256 was grown in a medium containing glucose $2 \%$, oatmeal $2 \%$, beef extract $0.3 \%, \mathrm{CaCO}_{3} 0.3 \%, \mathrm{NaCl} 0.3 \%, \mathrm{MnCl} \cdot 4 \mathrm{H}_{2} \mathrm{O}$ $0.04 \%$, and $\mathrm{Fe}_{2}\left(\mathrm{SO}_{4}\right)_{3} \cdot \mathrm{nH}_{2} \mathrm{O} 0.04 \%$, the $\mathrm{pH}$ of which was adjusted to 7.0 prior to sterilization at $121^{\circ} \mathrm{C}$ for 20 minutes. To the $100 \mathrm{ml}$ culture in a $500 \mathrm{ml} \mathrm{flask,} 1 \mathrm{ml}$ of sodium acetate solution $\left(30 \mathrm{mg} / \mathrm{ml}\right.$ for $\left[1-{ }^{13} \mathrm{C}\right]-$ or $\left[2-{ }^{13} \mathrm{C}\right]$ sodium acetate, $14 \mathrm{mg} / \mathrm{ml}$ for $\left[1,2-{ }^{13} \mathrm{C}_{2}\right]$ sodium acetate) was added repeatedly at the time of 24,36 , and 48 hours after inoculation. After 96 hours of incubation at $28^{\circ} \mathrm{C}$ on a rotary shaker $(200 \mathrm{rpm})$, the reddish culture (2.4 liter) was centrifuged, and the mycelia were extracted twice with $500 \mathrm{ml}$ of acetone. After concentration of the extract in vacuo, water was added, and the mixture was further extracted with $\mathrm{CHCl}_{3}$ at $\mathrm{pH}$ 5. The solvent of the extract was removed and the crude residue was purified repeatedly by chromatography with a ODS (Chromatorex DM1020T) column, first with an 85\% $\mathrm{MeOH}$ solvent, then with $70 \% \mathrm{MeOH}$ solvent to give red amorphous powder, which was recrystalized from
$\mathrm{CHCl}_{3}$-methanol to give $10 \sim 17 \mathrm{mg}$ of labeled FD-594.

$$
\text { Acknowledgment }
$$

This work was supported by "Research for the Future" Program of The Japan Society for the Promotion of Science (JSPS-RFTF96I00302).

\section{References}

1) Qiao, Y.; T. Okazaki, T. Ando, K. Mizoue, K. Kondo, T. EGUCHI \& K. KAKINUMA: Isolation and characterization of a new pyrano $\left[4^{\prime}, 3^{\prime}: 6,7\right]$ naphtho-[1,2-b]xanthene antibiotic FD-594. J. Antibiotics 51: 282 287, 1998

2) Ojiri, K.; H. Nishioka, K. Torigoe, S. Nakajima, K. Kawamura \& H. Suda: Antitumoric antibiotic BE13793X and its derivative BE-13793XA manufacture with streptoverticillium. Jpn. Kokai Tokkyo Koho JP $07,258,93[95,258,93]$

3) Herbert, K.; H. W. Fehlhaber, C. M. Mather, D. J. Upadhyay, L. E. L. Coutinho, B. N. Ganguli \& J. BlumbaCH: Novel antibiotic MSO901809 and MSO901809H, and thier production. Eur. Pat. Appl. EP 512,522

4) William, R. R \& R. J. Brown: Total synthesis of carbohydrates. 3. Efficient enantioselective syntheses of 2,6-dideoxyhexoses. J. Org. Chem. 48: 5093 5101, 1988

5) Vischer, E. \& T. Reichstein: Synthese des 2-Desoxy-dchinovose-3-methyläthers ( $d$-Oleandrose). Helv. Chim. Acta 27: 1332 1345, 1944

6) Kakushima, M.; Y. Sawada, M. Nishio, T. Tsuno \& T. OKI: Biosynthesis of pradimicin A. J. Org. Chem. 54: 2536 2539, 1989

7) Kakinuma, S.; K. Suzuki, M. Hatori, K. Saitoh, T. Hasegawa, T. Furumai \& T. OKI: Biosynthesis of the pradimicin family of antibiotics. J. Antibiotics 46: $430 \sim 440,1993$

8) Gomi, S.; M. Sezaki, M. Hamada, S. Kondo \& T. TAKEUCHI: Biosynthesis of benanomicins. J. Antibiotics 42: $1145 \sim 1150,1989$ 